\title{
GENETIC VARIATION IN THREATENED CONIFER CUNNINGHAMIA LANCEOLATA var. KONISHII USING ISSR MARKERS: IMPLICATIONS FOR CONSERVATION
}

\author{
NGUYEN MINH TAM, NGUYEN THI HOA \\ Vietnam National Museum of Nature \\ NGUYEN T. PHUONG TRANG \\ Institute of Ecology and Biological Resources
}

\begin{abstract}
We investigated the genetic variation of Cunninghamia lanceolata var. konishii, on basis of eight ISSR markers. Samples from 182 trees of four populations in the Thanh Hoa and Nghe An provinces were included in this study. The ISSR data showed low genetic variability at both population and species level, with an average of 0.1025 and 0.1357 , respectively. Genetic differentiation among populations was high $(\mathrm{Gst}=0.2554)$ indicating limited gene flow $(\mathrm{Nm}=1.4575)$. The implication of the results from the study to conserve genetic resources of the species was proposed.
\end{abstract}

Key words: C. lanceolata var. konishii, ISSR markers, genetic diversity, species conservation.

The conifers (Gymnosperms) are an ancient group of seed plants. They first appeared over 300 million years ago and came to form the dominant vegetation for long time. Conifers are characterized by naked seeds. Hermaphrodite cones do not occur and thus conifers are dioecious or monoecious. Outbreeding is frequently obligate. They are always windpollinated. Pollen grain has two lateral air sacs and are remarkably mobile. Pollen is received at the micropile of the ovule in a sticky drop of liquid containing both sugars and amino acids, through the micropile to the pollen chamber, adjacent to nucellus, where it germinates to form the male gametophyte. The pollen tube grows through the nucellus to the archegonial chamber, where it releases both sperm cells (male gametes). Two sperm cells are released in the archegonial chamber, where one will fuse with an egg in one of the archegonia. Many conifers produce woody cones. Seeds are usually winged.

Cunninghamia lanceolata var. konishii has a restricted distribution in Vietnam. It is confined to the border areas of Viet-Laos in two provinces Thanh Hoa and Nghe An; and extending to China and Laos [16]. It is found in pure stands on top ridges of limestone

66 mountains and has also been recorded in dense evergreen subtropical forest on granite derived soil above $900 \mathrm{~m}$ above sea level. It has a scattered distribution in little disturbed forests along the mountains slopes in Khe Thoi, reaching altitudes of $1500-1800 \mathrm{~m}$ in the $\mathrm{Pu}$ Mat National Park, Bat Mot, 1300-1400 m in the Xuan Lien Nature Reserve and $1900 \mathrm{~m}$ in the secondary forests in Tay Son. C. lanceolata var. konishii prefers relatively high humidity, ranging from $81 \%$ in Tuong Duong to $86 \%$ in $\mathrm{Pu}$ Mat. The annual precipitation is about 1260 $\mathrm{mm}$ in Tuong Duong and $1936 \mathrm{~mm}$ in Thuong Xuan (Thanh Hoa). Winter with low temperature and little precipitation lasts 4 months.

Populations of $C$. lanceolata var. konishii in fragmented habitats are usually small in size. Due to fluctuations in the number of individuals through random demographic and environmental forces, such small populations face an increased probability of extinction. Small and isolated populations often suffer from a reduction in gene flow, increased random genetic drift and inbreeding [2]. Consequently, there will be a decrease in genetic diversity, which might result in reduced fitness and increased susceptibility to 
environmental stochaticity.

At present there is very little information on ecology of $C$. lanceolata var. konishii, and especially data on the genetic variation within this species is lacking. The objective of this study was to use ISSR markers to investigate the genetic variation within $C$. lanceolata var. konishii and to develop strategies for the conservation of this species.

The previous studies conducted in population genetics of various conifers showed that low level of genetic differentiation among populations [10, 14]. In Abies sibirica [13], a low level of genetic variation and that of genetic differentiation among populations were revealed in Middle Siberia. In another species, Abies species [1] demonstrated the low genetic variation within populations and high genetic differentiation among populations from Southern Mexico and Guatemala in comparison to the most coniferous species reported.

\section{MATERIALS AND METHODS}

Plant materials. The research was carried out at four sites: three in Nghe An and one in Thanh Hoa (fig. 1 and table 1). The three sites were located within Nghe An province and the various types of disturbed habitats were described. At Khe Thoi (KT) and Bat Mot (XL), original vegetations have been lightly disturbed. Its structure is complex and includes three strata. The canopy comprises the tallest trees and is usually discontinuous. They may grow as high as $35-40 \mathrm{~m}$ with $0.5-3 \mathrm{~m}$ in breast height diameter (dbh). Besides species in Fagaceae, the canopy is also dominated by species of Altigiaceae, Elaeocarpaceae, Lauraceae and Dipterocarpaceae. Some conifers appear scattered in this layer. The understorey is composed of trees that are fairly close together to form a continuous layer, with high number of species. It is made up of young trees of the canopy and species of Theaceae, Rosaceae, Euphorbiaceae. The ground layer is more complex with species of Rubiaceae, Poaceae, Acanthaceae and Zingiberaceae. The original vegetations at Tay Son (TS) and Tam Hop (TH), especially at Tay Son, have been greatly degraded by human activities such as cutting of trees for fuel and buildings and to create an environment for light-demanding species. However, three strata also characterize this vegetation structure. The vegetation with drained soil, tall canopies up to $25-30 \mathrm{~m}$, wet and warm summer, dry and cool winter observed at these sites. The composition and structure of the vegetation were determined by the degree of disturbance. Dominant species were Pometia pinnata (Sapindaceae), Wrightia tonkiensis (Apocynaceae), Lithocarpus conmea (Fagaceae), Dipterocarpaceae, Lauraceae and Fabaceae and Neohousa spp. (Poaceae), light abundant favourable species. Shrubs include species of Araceae, Zingiberaceae and Rubiaceae. These altered the spatial distribution and age class structure of trees in these sites.

Table 1

Collect locations of Cunninghamia lanceolata var. konishii for ISSR analysis

\begin{tabular}{|c|c|l|c|c|c|}
\hline Population & Samples size & \multicolumn{1}{|c|}{ Collect lacation } & Altitude & Latitude & Longitude \\
\hline KT & 31 & $\begin{array}{l}\text { Khe Thoi, Con Cuong, } \\
\text { Nghe An }\end{array}$ & $1540 \mathrm{~m}$ & $19^{\circ} 05^{\prime} \mathrm{N}$ & $104^{\circ} 37^{\prime} \mathrm{E}$ \\
\hline TH & 55 & $\begin{array}{l}\text { Tam Hop, Tuong Duong, } \\
\text { Nghe An }\end{array}$ & $1350 \mathrm{~m}$ & $19^{\circ} 06^{\prime} \mathrm{N}$ & $104^{\circ} 21^{\prime} \mathrm{E}$ \\
\hline TS & 65 & $\begin{array}{l}\text { Tay Son, Ky Son, } \\
\text { Nghe An }\end{array}$ & $1900 \mathrm{~m}$ & $19^{\circ} 22^{\prime} \mathrm{N}$ & $104^{\circ} 21^{\prime} \mathrm{E}$ \\
\hline XL & 31 & $\begin{array}{l}\text { Bat Mot, Thuong Xuan, } \\
\text { Thanh Hoa }\end{array}$ & $1345 \mathrm{~m}$ & $20^{\circ} 02^{\prime} \mathrm{N}$ & $104^{\circ} 57^{\prime} \mathrm{E}$ \\
\hline
\end{tabular}

In this study, 182 sample individuals from 4 known populations were used. The collected samples were wrapped by markered aluminum paper and placed in liquid nitrogen. They were 
tranfered to Laboratory of Molecular Biology, Institute of Ecology and Biological Resources and subsequently, stored at $-76^{\circ} \mathrm{C}$ until the use for DNA extraction. The samples were identificated on basis of past taxonomic treatments of collected specimens from these populations.

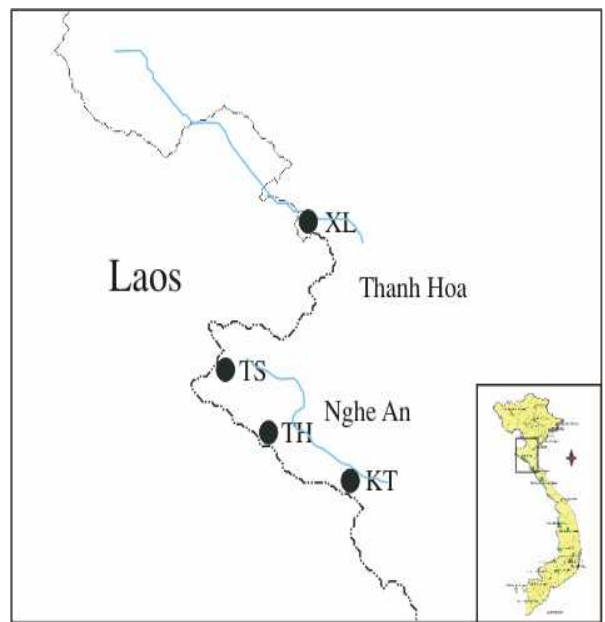

Fig. 1. Map showing the studying sites of $C$. lanceolata var. konishii

DNA extraction. Genomic DNA was extracted from young leaves (seedlings) or inner barks (adult trees) using the modified CTAB method by Xavier and Karine [19]. About 100 $\mathrm{mg}$ of leaves (or inner barks). Subsequently, the extraction buffer consisting of $640 \mu \mathrm{l}$ of CTAB extraction buffer $(100 \mathrm{mM}$ Tris- $\mathrm{HCl} \mathrm{pH} 8.0,20$ $\mathrm{mM}$ EDTA $\mathrm{pH} 8.0,1.4 \mathrm{M} \mathrm{NaCl}$ and $0.2 \% \beta$ mercaptoethanol) and $160 \mu \mathrm{l}$ of $10 \%$ CTAB was added, and the mixture was incubated at $60^{\circ} \mathrm{C}$ for 1 hour (leaves) or 3 hours (inner barks).
Then, $500 \mu \mathrm{l}$ phenol:chloroform:isoamylalcohol (25: $24: 1)$ was added to mixture gently for 5 min to form an emulsion and centrifuged at $10,000 \mathrm{~g}$ for $6 \mathrm{~min}$. DNA was precipitated by adding $2 / 3$ volume of cold isopropanol solution and refrigerate for $20 \mathrm{~min}$ to the supernatant. The DNA pellet was washed with $200 \mu$ l of $5 \mathrm{M}$ ammonium acetate and $600 \mu \mathrm{l}$ of absolute ethanol, dried by air pump and dissolved in TE buffer $(10 \mathrm{mM}$ Tris-HCl $\mathrm{pH} 8.0$ and $1 \mathrm{mM}$ EDTA pH 8.0) with $1 \mu \mathrm{l}$ RNase $(1 \mu \mathrm{g} / \mathrm{ml})$ per $100 \mu \mathrm{l}$ DNA. The concentration of total DNA was determined using a fluorometer.

DNA amplification for ISSR. Polymerase chain reaction (PCR) was carried out in $25 \mu 1$ solution consisting of $2.5 \mu \mathrm{l} 10 \mathrm{X}$ reaction buffer, $2.5 \mu \mathrm{l} \mathrm{MgCl} 2,2 \mu \mathrm{l} \mathrm{dNTP}, 0.1 \mu \mathrm{l}$ of primer, 1.25 units Taq DNA polymerase (Invitrogen) and $1.5 \mu \mathrm{l}$ of template DNA. A total of eight ISSR primers were used in this study (table 2). The reaction mixture was subjected to amplification in the Gene Amp PCR System 2400, under the following thermal cycler: an initial denaturing step at $94^{\circ} \mathrm{C}$ for 4 min, followed by 35 cycles consisting of $1 \mathrm{~min}$ at $94^{\circ} \mathrm{C}, 30 \mathrm{~s}$ annealing temperature for each primer (Table 2) and $1 \mathrm{~min}$ extension at $72^{\circ} \mathrm{C}$, and $10 \mathrm{~min}$ at $72^{\circ} \mathrm{C}$ for a final cycle to complete the extension of any remaining products before holding the samples at $4^{\circ} \mathrm{C}$ until analyzed. The amplification products were separated by electrophoresis on $7.5 \%$ polyacrylamide gels in $1 \times$ TAE buffer, and then stained by ethidium bromide for $10 \mathrm{~min}$. The banding patterns were visualized under UV light and photographed using a MEGA 8.4 Panasonic camera. $1 \mathrm{~kb}$ ladder was used as DNA standard (Invitrogen).

Table 2

List of primers used for ISSR amplification (Y: C or T)

\begin{tabular}{|c|l|c|}
\hline Primer code & \multicolumn{1}{|c|}{ Primer sequences (5' to 3') } & Annealing temperature $\left.\mathbf{(}^{\mathbf{0}} \mathbf{C}\right)$ \\
\hline UBC810 & GAG AGA GAG AGA GAG AT & 40 \\
\hline UBC811 & GAG AGA GAG AGA GAG AC & 40 \\
\hline UBC815 & CTC TCT CTC TCT CTC TG & 40 \\
\hline UBC835 & AGA GAG AGA GAG AGA GYC & 45 \\
\hline UBC836 & AGA GAG AGA GAG AGA GYA & 40 \\
\hline UBC840 & GAG AGA GAG AGA GAG AYT & 45 \\
\hline UBC841 & GAG AGA GAG AGA GAG AYC & 45 \\
\hline UBC857 & ACA CAC ACA CAC ACA CYG & 46 \\
\hline
\end{tabular}




\section{Data analysis}

Genetic diversity analyses. ISSR bands were scored as presence (1) or absence (0). The binary data were analysed by PopGene v.1.31 [22] to estimate genetic diversity parameters: the effective number of alleles per locus (Ae), the proportion of polymorphic loci (P), the Nei's (1973) gene diversity $(\mathrm{H})$ and the Shannon's index (I).

Genetic diversities within and among the populations were analyzed for each polymorphic locus using Nei's (1987) genetic diversity statistics: the total genetic diversity $(\mathrm{Ht})$, the genetic diversity within populations (Hs), the coefficient of genetic diversity (Gst). The genetic differentiation among populations was estimated from allele frequencies using Nei's (1972) genetic distance and identify for all pairs of populations. UPGMA cluster analysis of genetic distances was generated to examine genetic associations among populations or among individuals within populations using Nei's (1972) genetic distance.

The gene flow between populations $(\mathrm{Nm})$ was also determined using Gst value: $\mathrm{Nm}=0.5$ (1-Gst)/Gst.

\section{RESULTS}

The eight ISSR primers produced a total of 115 bands across all 182 individuals of four $C$. lanceolata var. konishii populations (table 3 ). The proportion of polymorphic bands was 97.39\% (112 bands). The mean number of polymorphic bands per primer was 14 in the size range of 150 to $1000 \mathrm{bp}$. Maximum number of bands were yielded by the repeat (AC) ${ }_{8} \mathrm{YG}$ with 19 bands. Minimum bands were yielded by $(\mathrm{GA})_{8}$ YT with 10 bands.

Table 3

Primers, number of fragments scored, number of polymorphic bands and percentage polymorphism from amplification profiles of 182 individuals of $C$. lanceolata var. konishii generated using eight ISSR markers

\begin{tabular}{|c|c|c|c|c|}
\hline $\begin{array}{c}\text { Primer } \\
\text { repeat }\end{array}$ & Code & $\begin{array}{c}\text { No. of fragments } \\
\text { scored }\end{array}$ & $\begin{array}{c}\text { No. of polymorphic } \\
\text { fragments }\end{array}$ & $\begin{array}{c}\text { Percent } \\
\text { polymorphism }\end{array}$ \\
\hline$(\mathrm{GA})_{8} \mathrm{~T}$ & $\mathrm{UBC} 810$ & 13 & 13 & 100.00 \\
\hline$(\mathrm{GA})_{8} \mathrm{C}$ & $\mathrm{UBC} 811$ & 12 & 12 & 100.00 \\
\hline$(\mathrm{CT})_{8} \mathrm{G}$ & $\mathrm{UBC} 815$ & 16 & 15 & 93.75 \\
\hline$(\mathrm{AG})_{8} \mathrm{YC}$ & $\mathrm{UBC} 835$ & 14 & 14 & 100.00 \\
\hline$(\mathrm{AG})_{8} \mathrm{YA}$ & $\mathrm{UBC} 836$ & 15 & 15 & 100.00 \\
\hline$(\mathrm{GA})_{8} \mathrm{YT}$ & $\mathrm{UBC} 840$ & 10 & 9 & 90.00 \\
\hline$(\mathrm{GA})_{8} \mathrm{YC}$ & $\mathrm{UBC} 841$ & 15 & 14 & 93.33 \\
\hline$(\mathrm{AC})_{8} \mathrm{YG}$ & $\mathrm{UBC} 857$ & 19 & 19 & 100.00 \\
\hline $\mathrm{All}$ & & 115 & 112 & 97.39 \\
\hline
\end{tabular}

Genetic diversities are shown in Table 4. At the population level, the $\mathrm{P}$ value ranged from $40 \%$ (KT) to $58.26 \%$ (TS), an average of $49.35 \%$. H ranged from 0.0898 (KT) to 0.1178 $(\mathrm{TH})$, an average of 0.1025 , and I ranged from 0.1436 (KT) to $0.1867(\mathrm{TH})$, an average of 0.1561 (table 4). At species level, these values were $\mathrm{P}=97.39 \%, \mathrm{H}=0.1357$ and $\mathrm{I}=0.2355$. Genetic diversities were found in adult and seedling populations at Tam Hop and Tay Son. Our results showed that genetic diversities were lower in adult than in seedling populations in both Tam Hop and Tay Son. These values were
$\mathrm{P}=37.39 \%, \mathrm{H}=0.0959$ and $\mathrm{I}=0.1524$ for adult trees at Tam Hop; $\mathrm{P}=35.65 \%, \mathrm{H}=$ $0.0723, \mathrm{I}=0.1166$ (Tay Son); and $\mathrm{P}=49.57 \%$, $\mathrm{H}=0.1137, \mathrm{I}=0.1773$ for seedlings at Tam Hop; $\mathrm{P}=44.35 \%, \mathrm{H}=0.977, \mathrm{I}=0.1544$ (Tay Son). As shown in Table 5, the total genetic (Ht) among all the populations of $C$. lanceolata var. konishii was found to be 0.1377 , whereas, an average of the genetic diversity within populations (Hs) was 0.1025 . The coefficient of genetic differentiation (Gst) was 0.2554. The gene flow $(\mathrm{Nm})$ calculated among all the populations of $C$. lanceolata var. konishii was 
high. Genetic identities and distances from all pairwise comparisons of $C$. lanceolata var. konishii populations are shown in Table 6. Genetic identity averaged 0.9478 , ranging from
0.9285 (TH and KT) to 0.9657 (TS and TH). The mean genetic distance between populations was 0.0537 , ranging from 0.0349 (TS and $\mathrm{TH}$ ) to 0.0742 (KT and TH).

Table 4

Genetic diversity in four C. lanceolata var. konishii populations

\begin{tabular}{|c|c|c|c|c|c|}
\hline Populations & N & Ae & P & H (s.d.) & I (s.d.) \\
\hline KT & 24 & $\begin{array}{c}1.144 \\
(0.273)\end{array}$ & 40.0 & $\begin{array}{c}0.0898 \\
(0.1528)\end{array}$ & $0.1436(0.2238)$ \\
\hline TH & 47 & $\begin{array}{c}1.192 \\
(0.309)\end{array}$ & 53.91 & $\begin{array}{c}0.1178 \\
(0.1695)\end{array}$ & $0.1867(0.2439)$ \\
\hline TS & 58 & $\begin{array}{c}1.164 \\
(0.282)\end{array}$ & 58.26 & $\begin{array}{c}0.1038 \\
(0.1559)\end{array}$ & $0.1699(0.2250)$ \\
\hline XL & 19 & $\begin{array}{c}1.151 \\
(0.257)\end{array}$ & 45.22 & $\begin{array}{c}0.0985 \\
(0.1486)\end{array}$ & $0.1604(0.2210)$ \\
\hline Mean & & & 49.35 & 0.1025 & 0.1651 \\
\hline All & 148 & $\begin{array}{c}1.195 \\
(0.247)\end{array}$ & 97.39 & $\begin{array}{c}0.1357 \\
(0.1380)\end{array}$ & $0.2355(0.1938)$ \\
\hline
\end{tabular}

Notes: N. the mean number of individuals sampled; Ae. the effective number of alleles per locus; P. the proportion of polymorphic loci; H. Nei's (1973) genetic diversity; I. Shannon's Information index.

Table 5

Nei's (1987) genetic diversity within and among populations of some species of conifers

\begin{tabular}{|l|c|c|c|c|c|c|}
\hline & N & Hs & Ht & Gst & Nm & References \\
\hline C. lanceolata var. konishii & 148 & $\begin{array}{c}0.1025 \\
(0.0096)\end{array}$ & $\begin{array}{c}0.1377 \\
(0.0177)\end{array}$ & 0.2554 & 1.4575 & This study \\
\hline Pseudotsuga menziesii & - & 0.1546 & 0.1594 & 0.0260 & - & {$[24]$} \\
\hline Picea sitchensis & - & 0.147 & 0.159 & 0.079 & - & {$[23]$} \\
\hline Pinus longaeva & - & 0.465 & 0.484 & 0.038 & - & {$[8]$} \\
\hline P. rigida & - & 0.147 & 0.152 & 0.03 & - & {$[5]$} \\
\hline
\end{tabular}

The clustering of C. lanceolata var. konishii populations using the UPGMA method based on paiwise genetic distances showed the XL population is closer to the group containing the TH and TS populations than do KT population.

\section{Table 6}

Nei's (1972) original measures of genetic identity (above diagonal) and genetic distance (below diagonal)

\begin{tabular}{|l|l|l|l|l|}
\hline & \multicolumn{1}{|c|}{ KT } & \multicolumn{1}{c|}{ XL } & \multicolumn{1}{c|}{ TS } & \multicolumn{1}{c|}{ TH } \\
\hline KT & - & 0.9432 & 0.9356 & 0.9285 \\
\hline XL & 0.0584 & - & 0.9652 & 0.9488 \\
\hline TS & 0.0666 & 0.0354 & - & 0.9657 \\
\hline TH & 0.0742 & 0.0525 & 0.0349 & - \\
\hline
\end{tabular}

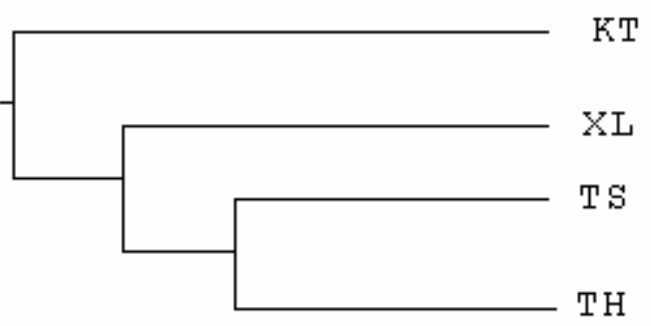

Fig. 2. UPGMA dendrogram based on Nei's (1972) genetic distances among four $C$. lanceolata var. konishii populations

Discussion: ISSR markers were used to assess genetic diversity measures within and among populations of $C$. lanceolata var. konishii in this study. Both population and species levels have lower values of genetic diversities than those of 
many other coniferous species. High values of genetic variability have been reported for populations of many conifers such as Pinus strobus: $\mathrm{P}=47.8 \%$ and $\mathrm{H}=0.195$ [17], Pinus pinceana: $\mathrm{P}=56.5 \%, \mathrm{H}=0.174$ [14] and Pinus brutia: $\mathrm{P}=68 \%, \mathrm{H}=0.271$ [12]. Low genetic variabilities have been also found in some conifers with a limited distribution: Abies sibirica: $\mathrm{P}=20 \% \mathrm{H}=0.0642$ [13], A. flinckii: $\mathrm{P}$ $=30.2 \%, \mathrm{H}=0.113$, A. guatemalensis: $\mathrm{P}=$ $20 \%, \mathrm{H}=0.069$, A. hickeli: $\mathrm{P}=28.2 \%, \mathrm{H}=0.1$ A. religiosa: $\mathrm{P}=31.8 \%, \mathrm{H}=0.108$ [1], $A$. lasiocarpa $\mathrm{P}=43.4 \% \mathrm{H}=0.124$ [18] and Picea breweriana: $\mathrm{P}=44.2 \% \mathrm{H}=0.129$ [15]. In another studies, high levels of genetic variability within and among conifers were also obtained: Picea sitchensis: $\mathrm{Hs}=0.147$ and $\mathrm{Ht}=0.159$ [23], Pinus longaeva: $\mathrm{Hs}=0.465, \mathrm{Ht}=0.484$ [8] and $P$. rigida: $\mathrm{Hs}=0.147, \mathrm{Ht}=0.152$ [5]. Our results confirm the suggestion that the genetic structure of natural populations of $C$. lanceolata var. konishii is strongly affected by small population sizes. The number of observed individuals in each area was small and varied considerably, in Khe Thoi and Bat Mot, in the relatively undisturbed forests inside $\mathrm{Pu}$ Mat National Park and Xuan Lien Nature Reserve, the average population size approximately 100 individuals. In contrast, the population sizes at secondary forests of Tam Hop and Tay Son are smaller (75 and 68 individuals, respectively) due to the exploitation from local people for their buildings and other purposes. Such small populations are at risk of inbreeding and the effects of genetic drift [2, 3, 9]. The current distribution of $C$. lanceolata var. konishii has been strongly influenced by fragmented habitats. The species are distributed in the forests at 1300-1900 m elevation. There, forests have been greatly fragmented by human activities and form small forest patches. A few natural populations of $C$. lanceolata var. konishii remain in such small patches. The logging activity and the associated creation of gaps have caused a change in original vegetation structure. There was variation in the spatial distribution, age class structure of trees and the invasion of exotic species. C. lanceolata var. konishii distribution is characteristic terrain and climate. Therefore, the species has been exposed to geographic isolation. The results also showed that genetic parameters made on the adult trees were lower than those made on the seedlings at both Tay Son (TS) and Tam Hop (TH). It is related to disperse on large distances. The seeds are dispersed by wind.

A limited genetic variability within populations also indicated considerable levels of differentiation among populations. The stimates of the Gst value for C. lanceolata var. konishii populations showed high amounts of genetic differentiation $(\mathrm{Gst}=0.2554)$. This value was clearly higher than those reported in other coniferous species, such as Pseudotsuga menziesii Gst $=0.026$ [24], Pinus longaeva Gst $=0.038$ [8], Pinus sibirica Gst $=0.041$ [4], Pinus monophylla Gst $=0.033$ [7], Pinus albicaulis Gst $=0.034$ [9] and Pinus flexilis Gst $=0.101$ [10]. In another cases, the Gst value detected was higher for Pinus attennuata Gst $=$ 0.24 and P. muricata Gst $=0.29$ [21]; Pinus brutia $\mathrm{Gst}=0.29$ in the Marmara region and Gst $=0.35$ in western Mediterranean region [11], Picea asperata Gst $=0.34$ [20]. The result confirms the assumption that genetic drift increased genetic differentiation among populations [3]. The high differentiation could be a consequence of limited gene flow $(\mathrm{Nm}=$ 1.4575). Fragmented habitat was gene flow barriers and decreased migration among populations for $C$. lanceolata var. konishii. Founder effects might contribute to the high level of genetic differentiation among the populations.

In conclusion, C. lanceolata var. konishii maintained low level of genetic variability and high level of genetic population differentiation. They are the results of human interference. $C$. lanceolata var. konishii habitat has been degraded and fragmented, and only a few natural populations survived. Based on a conservation point of view, effective management strategies for $C$. lanceolata var. konishii should include both in-situ and ex-situ activities. Establishment of seed orchards from all the populations should secure genetic sources of this species. Monitoring of the genetic variability in planted populations should be important to ensure that the high level of genetic diversity is maintained. 
Acknowledgments: This research is partially supported by Vietnam-Sweden Research Cooperation Fund (No 67-RF2).

\section{REFERENCES}

1. Aquirre-Planter et al., 2000: Amer. J. Bot. 87: 362-371.

2. Barrett and Kohn, 1991: Genetics and conservation of rare plants: 3-30. Oxford University Press.

3. Ellstrand N. C., Elam R. D., 1993: Plant Conservation Genetics, pp. 217-242.

4. Goncharenko G. G. et al., 1993: Silvae Genet., 42: 246-258.

5. Guries R. P. et al., 1982: Evolution, 36: 387-402.

6. Harl D. L., Clark A. G., 1989: Principles of population genetics. Sunderland, MA, Simaver Associates.

7. Hamrick J. L. et al., 1994: In KT Harper, Clair LLSt, Thome KH and Hess WW (eds.), Natural history of the Colorado plateau and great Basin: 147-161. University Colorado Press. Niwat, Colorado, USA.

8. Hichert R. D., Hamrick J. L., 1983: Evolution, 37(2): 302-311.

9. Jorgensen S. M., Hamrick J. L., 1997: Can. J. For. Research, 27: 1374-1385.

10. Jorgensen S. M. et al., 2002: Amer. J. Bot., 89(5): 792-800.

11. Kandermir G. E. et al., 2004: Silvae
Genet., 53(4\&5): 169-175.

12. Korol L. et al., 2002: Silvae Genet., 51(1): $35-41$.

13. Larionova A. Y. et al., 2007: Eurasian J. For. Res., 10-2: 185-192.

14. Ledig et al., 2001: Amer. J. Bot., 88(11): 1977-1987.

15. Ledig F. T. et al., 2005: Amer. J. Bot., 92(12): 1975-1986.

16. Luu and Thomas, 2004: Conifers of Vietnam. Foreign languages pub. Hou. Hanoi.

17. Rajora O. P. et al., 1998: Amer. J. Bot., 76: 500-508.

18. Shea K. L., 1990: Genom., 33: 1-8.

19. Xavier J. L., Karine L., 2000: Plant Molecular Biology Reporter, 18: 283a-283g.

20. Xue X. et al., 2005: Silvae Genet., 54(1): 24-30.

21. Wu J. et al., 1999: Genome 42: 893-908.

22. Yeh F. C., Boyle T., 1999: V.1.32: Microsoft windows-based freeware for population genetic analysis. Edmonton: University of Alberta.

23. Yeh F. C., El-Kassaby Y. A., 1979: I. Genetic variation patterns in ten IUFRO provenances. In. Proc. 52d Northwest sci. Assoc. Meet. Bellingham, Wash.

24. Yeh F. C., O’Malley D., 1980: Silvae Genet., 29: 83-92.

\title{
ĐA DẠNG DI TRUYỀN LOÀI SA MỘC DẦU (CUNNINGHAMIA LANCEOLATA var. KONISHII) BÀ̀NG CHİ THI ISSR: ÁP DỤNG CHO CÔNG VIẸC BẢO TỒN
}

NGUYỄN MINH TÂM, NGUYỄN THI HOA, NGUYỄN THI PHUOONG TRANG

\section{TÓM TẮT}

\begin{abstract}
Chúng tôi đã tiến hành điều tra đa dạng di truyền quần thể của loài sa mộc dầu (Cunninghamia langceolata var. konishii) ở Việt Nam, trên cơ sở 8 chỉ thị ISSR. Mẫu phân tích DNA được thu thập từ 182 cá thể từ 4 quần thể ở 2 tỉnh Thanh Hoá và Nghệ An. Dẫn liệu phân tích DNA đã chỉ ra rằng mức độ đa dạng di truyền quần thể và loài thấp, tương ứng ở mức độ quần thể và loài trung bình 0,1025 và 0,1357 . Mức độ khác nhau giữa các quần thể trong loài là cao, $\mathrm{Gst}=0,2554$ và chỉ ra giới hạn dòng gen $\mathrm{Nm}=1,4575$. Kết quả nghiên cứu đã được thảo luận và đề xuất để bảo tồn nguồn gen hữu hiệu cho loài sa mộc dầu nói riêng và các loài trong họ Hoàng đàn (Cuppessaceae) nói chung.
\end{abstract}

Ngày nhận bài: 18-3-2008 